\title{
Ergenler için Psikolojik Zihinlilik Ölçeğinin Geliştirilmesi: Geçerlik ve Güvenirlik Çalışması
}

\section{Development of Psychological Mindedness Scale for Adolescents: Validity and Reliability Study}

\author{
Kıvanç UZUN*, Özlem TAGAY**, Zeynep KARATAŞ***
}

\begin{abstract}
Öz: Bu araştırmanın amacı ergenlerin psikolojik zihinliliklerini belirlemek üzere geliştirilen Ergenler için Psikolojik Zihinlilik Ölçeğinin (EPZÖ) geçerlik ve güvenirlik çalışmasını yapmaktır. Araştırmanın çalışma grubu, 2019-2020 eğitim öğretim yılında Muğla'nın Bodrum ilçesinde öğrenim gören ve uygun örneklem yöntemiyle seçilen 670 kadın ve 584 erkek olmak üzere toplam 1254 lise öğrencisinden oluşmaktadır. Ölçeğin faktör yapısı açımlayıcı ve doğrulayıcı faktör analizi ile incelenmiş ve toplam varyansın \%50.95'ini açılayan dört boyutlu bir yapı elde edilmiştir. Bu yapının model uyumunun iyi düzeyde olduğu bulunmuştur $\left(X_{2} / \mathrm{sd}=1.51\right.$, RMSEA $=.045, \mathrm{RMR}=.075, \mathrm{SRMR}=.057$, NFI=.90, NNFI=.96, CFI=.96, $\mathrm{IFI}=.96, \mathrm{RFI}=.91, \mathrm{AGFI}=.89, \mathrm{GFI}=.91$ ). Ölçeğin güvenirliğini belirlemek için iç tutarlılık, iki yarı ve test tekrar test güvenirlik analizleri yapılmış ve ölçeğin güvenilir olduğuna karar vermek için kabul edilebilir değerlere ulaşılmıştır. Araştırmadan elde edilen bulgular doğrultusunda; geliştirilmiş olan Ergenler için Psikolojik Zihinlilik Ölçeğinin, lise öğrencilerinin psikolojik zihinlilik düzeylerini belirleme sürecinde kullanılabilecek, geçerliği ve güvenirliği olan bir ölçme aracı olduğu sonucuna ulaşılmıştır.
\end{abstract}

Anahtar Kelimeler: Ergenlik, lise, psikolojik zihinlilik, ölçek geliştirme, faktör analizi

\begin{abstract}
The purpose of the current study is to conduct the validity and reliability studies of the Psychological Mindedness Scale for Adolescents (PMSA) developed to determine the psychological mindedness of adolescents. The study group of the current research is composed of a total of 1254 high school students (670 females and 584 males) attending high schools in the Bodrum district of the city of Muğla in 2019-2020 school year and selected through the convenience sampling method. The factor structure of the scale was investigated with exploratory and confirmatory factor analyses and a fourdimensional construct explaining $50.95 \%$ of the total variance was obtained and the fit of this construct was found to be good $\left(X_{2} / \mathrm{sd}=1.51\right.$, RMSEA $=.045$, RMR $=.075, \mathrm{SRMR}=.057, \mathrm{NFI}=.90, \mathrm{NNFI}=.96, \mathrm{CFI}=.96$, $\mathrm{IFI}=.96$, RFI=.91, AGFI=.89, GFI=.91). In order to determine the reliability of the scale, internal consistency, split-half and test-retest reliability analyses were run and acceptable values showing that the scale is reliable were obtained. On the basis of the findings of the current study, it was concluded that the Psychological Mindedness Scale for Adolescents is a reliable and valid scale that can be used in the process of determining the psychological mindedness level of high school students.
\end{abstract}

Keywords: Adolescence, high school, psychological mindedness, scale development, factor analysis

\section{Giriş}

Bireylerin ruh sağlığı uzmanlarından aldığı psikolojik yardımın etkililiği uzun yıllardır araştırma konusu olmuştur. Psikolojik yardımın etkililiğini arttırmak için ne gibi faktörlerin üzerinde durulması gerektiğine dair çalışmalar uzun zamandan beri yapılmaktadır (Lambert ve Ogles, 2004; Orlinsky, Rønnestad ve Willutzki, 2004). Yapılan çalışmalar, özellikle psikolojik danışmanın yeterliği, terapötik becerileri, başa çıkma stratejileri ve kullandığı teknikler gibi değişkenlerin üzerinde durmaktadır. Psikolojik danışmana ait bu özelliklerin, psikolojik yardım sürecinin niteliğini ne ölçüde etkilediği, çalışılmaya devam edilen konular arasındadır (Beutler ve

\footnotetext{
* Öğr. Gör., Burdur Mehmet Akif Ersoy Üniversitesi, Mezunlarla İlişkiler ve Kariyer Planlama Koordinatörlüğü, Burdur, Türkiye, ORCID: 0000-0002-6816-1789, e-posta: kuzun@mehmetakif.edu.tr

** Doç. Dr., Burdur Mehmet Akif Ersoy Üniversitesi, Eğitim Fakültesi, Burdur, Türkiye, ORCID: 0000-0002-98215960, e-posta: ozlemtagay@gmail.com

*** Prof. Dr., Burdur Mehmet Akif Ersoy Üniversitesi, Eğitim Fakültesi, Burdur, Türkiye, ORCID: 0000-0002-45326827, e-posta: zeynepkaratas1972@ @otmail.com
} 
diğerleri, 2004; Hill ve Lambert, 2004). Bu bağlamda psikolojik danışma yardımı sunarken, danışma sürecindeki terapötik değişkenler ile danışanların farklı kişilik özelliklerinin birbirini nasıl etkilediğini anlamanın çok kritik olduğu söylenebilir. Türkiye'de özellikle son yıllarda psikolojik danışma sürecinde, danışanın ve psikolojik danışmanın özelliklerinin; psikolojik yardım sürecini ne ölçüde etkilediğine dair araştırmaların sayısının arttı̆̆ı görülmektedir (Denizli, 2010; İşlegen, 2011; Sanberk, 2010).

Psikolojik yardım alanında yapılan çalışmalar da çoğunlukla psikolojik danışmanın sahip olması gereken özellikler üzerinde durulsa da yardım almaya gelen her bir danışanın kendine özgü bireysel farklılıklarının olduğu unutulmamalıdır. Danışanların yardım alma sürecine farklı kişilik özellikleri, koşul ve tutumlar içerinde geldiği göz önüne alındığında; danışana dair özelliklerinde psikolojik yardım alma sürecinde çok önemli bir yere sahip olduğu göz ardı edilemeyecektir. Her bir danışanın gelişimsel hikâyesi, sosyal becerileri, zihinsel yetenekleri, problemlerinin ciddiyeti ve yoğunluğu, probleminden ne ölçüde etkilenmekte olduğu ve değişim konusundaki inanc1 kendine özgü ve farklıdır (Clarkin ve Levy, 2004).

Psikolojik yardım alma süreçlerinin etkililiğine bakıldığında, danışana dair özelliklerin, danışma sürecindeki diğer terapötik olmayan özelliklere göre süreçteki değişimi açılamada en yüksek orana sahip olduğu; ayrıca psikolojik yardım sürecinden sonraki değişimin de \%40'ının yine danışana ait özelliklere bağlı olduğu ileri sürülmektedir (Lambert, 1992). Assay ve Lambert (1999), çeşitli terapi yaklaşımlarını karşılaştırdıkları deneysel araştırmalarının sonuçlarına dayanarak tedavi sonucunun sadece \%15'inin belirli tekniklere bağlı olduğu bulgusunu elde etmişlerdir. Aynı araştırmada danışana bağlı değişkenlerin tedavi sonucunu büyük ölçüde etkilediği (\%40), bunu ilişki değişkenlerinin (\%30) takip ettiği, umut ve beklentilerin ise placebo olarak (\%15) tedaviyi etkilediği sonuçlarına ulaşılmıştır. Psikolojik yardım süreçlerine ilişkin yapılan çalışmalarda danışana dair incelenebilecek özelliklerin sayısı oldukça fazladır. Ancak yapılacak olan çalışmalarda danışanların sadece demografik özelliklerine göre psikolojik yardım alma süreçlerini ve sonuçlarını değerlendirmek oldukça yüzeysel olacaktır. Ayrıca alanyazın incelendiğinde danışanlara ait demografik özelliklere göre psikolojik yardım arama sürecinden ve sonucundan elde edilen bulguların, birbiriyle tutarlı olmadığı ve muğlâk olduğu görülmektedir (Clarkin ve Levy, 2004; Muran ve Lutz, 2015; Stiles, Hill ve Elliot, 2015). Bu bağlamda danışanların demografik özelliklerinin dışında psikolojik yardım alma süreçlerini etkilediği düşünülen ve dikkate alınması gereken; danışana ilişkin bazı kişisel niteliklerin araştırılmasının gerekliliği ortaya çıkmaktadır. Son yıllarda danışana ilişkin bir özellik olarak ortaya çıkan "psikolojik zihinlilik" (psychological mindedness) kavramı, psikolojik yardım alma sürecinin etkililiği araştırmalarının gündemine alınmıştır (Boylan, 2006; Conte, Ratto ve Karasu, 1996; Denizli, Lüleci ve Meydan, 2015; Denizli, Meydan ve Pamukçu, 2018; Denizli, Pamukçu ve Meydan, 2016; Grant, 2001; McCallum, Piper, Ogrodniczuk ve Joyce, 2003; Nyklíček ve Denollet, 2009; Nyklíček, Majoor ve Schalken, 2010; Piper, McCallum, Joyce, Roise ve Ogrodniczuk, 2001).

Psikolojik zihinlilik kavramının doğuşu ve gelişimine bakıldığında; ilk olarak danışanın psikanalitik terapiye ne ölçüde uygun olup olmadığının belirlenmesi amacıyla ortaya çıktığı görülmektedir. Bu açıdan psikolojik zihinlilik kavramı doğduğu ilk zamanlarda psikanalitik bir bakışla tanımlanmaya çalışılmıştır (Boylan, 2006). Alanyazın incelendiğinde psikolojik zihinlilik kavramının bugüne kadar yapılan diğer araştırmalarda öz-farkındalık, öz-bilinç, içgörü, kendine odaklanabilme, içebakış ve kendini gözleyebilme yetisi gibi kavramlarla aynı anlama gelecek şekilde kullanıldığı görülmektedir (McCallum ve Piper, 1996). Bu bağlamda Appelbaum (1973) göre psikolojik zihinlilik kavramı, bireylerin yaşantılarının ve sergiledikleri davranışların belirleyicisi olan nedenleri veya anlamsal şemaları öğrenebilmesi için düşünce, duygu ve davranışları arasındaki ilişkiyi görebilme becerisi olarak, psikanalitik içgörü kavramını da kapsayacak şekilde açıklanmıştır. Yakın zamanda yapılan çalışmalarda ise psikolojik zihinlilik kavramı, psikanalitik bakış açısından uzaklaşarak, yeni ve farklı bir psikolojik kavram olarak tanımlanmaya başlamıştır.

Conte ve diğerleri (1996) tarafından psikolojik zihinlilik kavramı, bireyin hem kendisinin hem de başkasının davranışlarını ve motivasyonunu anlamaya yönelik ilgi ve yeteneğin sahibi 
olması şeklinde tanımlanmıştır. $\mathrm{Bu}$ bağlamda psikolojik zihinlilik bireyin kendisini gözlemlemesiyle ilgili bir kavram olduğu kadar; aynı zamanda diğer insanların da sergiledikleri davranışları anlamasını sağlayan bir yapıdır. Psikolojik zihinlilik kavramı bu şekilde tanımlanmakla birlikte artık psikanalitik bir kavram olarak ifade edilmekten çıkıp, bilişsel bir süreç şeklinde ele alınmaya başlanmıştır (Beitel, Ferrer ve Cecero, 2004).

Bilişsel bakış açısıyla Grant (2001) psikolojik zihinliliği bir metabiliş (üstbiliş) olarak ele almış ve "bireyin kendisinin ya da diğerlerinin nasıl ve neden o şekilde davrandığını, düşündüğünü ve hissettiğini sorgulamaya dönük duygusal ve zihinsel bir yatkınlık" olarak tanımlamıştır. Boylan (2006) ise psikolojik zihinlilik kavramını bireyin duygularını anlamlandırabilme becerisi, yeni düşüncelere karşı açık olması, diğer insanları anlamak için hevesli olması ve ayrıca bireyin kendisinin ve diğer insanların davranışlarının altında yatan nedenlere ilgi duyması şeklinde ifade etmiştir. Nyklíček ve Denollet (2009) psikolojik zihinlilik kavramını, bireylerin içsel süreçlerinin ve psikolojik durumlarının farkında olmalarına yönelik bir çeşit ilgi ve yetenek olarak ele almışlardır.

Tüm bu tanımlar ele alındığında psikolojik zihinlilik kavramı, en geniş anlamıyla; bireyin kendisinin ve diğerlerinin davranışları altında yatan nedenleri anlamasını sağlayan, bir çeşit ilgi ve yetenek şeklinde değerlendirilebilir (Conte ve diğerleri, 1996; Grant, 2001). Alanyazın incelendiğinde yüksek psikolojik zihinliliğin bireylerin ruh sağlığını olumlu şekilde yordadığı görülmektedir. Bu konuda yapılan araştırmalar incelendiğinde psikolojik zihinlilik kavramının duygusal durum, güvengenlik, yaşantılara açıklık, sosyallik, güvenli bağlanma ve psikolojik yardım alma süreçlerinden yüksek düzeyde yararlanma ile pozitif yönde; nörotizm, somatizasyon, kaygı, uyku bozuklukları, depresyon ve kişiler arası çatışma düzeyi ile negatif yönde ilişkili olduğu ortaya konulmuştur (Beitel ve Cecero, 2003; Conte, Buckley, Picard ve Karasu, 1995; Trudeau ve Reich, 1995). Ayrıca Beitel ve diğerleri (2004) de psikolojik zihinliliği yüksek olan bireylerin bilişsel özelliklerini tespit etmeye çalıştıkları araştırmalarında, psikolojik zihinliliği yüksek olan bireylerin gerçekçi düşünme eğilimli, amaç yönelimli ve esnek profilde olduklarını belirlemiş̧lerdir. Bu bulgulardan yola çıkarak psikolojik zihinliliğe katkı sağlayan bu özelliklerin geliştirilmesinin, bireylerin psikolojik yardım alma süreçlerinden faydalanma düzeylerini de arttırılabileceği düşünülmektedir.

Piper ve diğerleri (2001) yas döneminde olan yetişkinlerle yaptıkları grup terapisinde, yüksek psikolojik zihinlilik düzeyinin; yas tepkilerinin azaltılmasında anlamlı ve pozitif bir yordayıcı rolü olduğunu tespit etmişlerdir. McCallum ve diğerleri (2003) yetişkinlerle yapmış oldukları hem kısa süreli bireysel terapide hem de kısa süreli grup terapisinde; danışanların psikolojik zihinliliğinin yüksek olmasının terapinin olumlu sonuçlarıla ilişkili olduğunu bulgulamışlardır. Beitel ve diğerleri (2009) tarafından üniversite öğrencileriyle yapılan bir araştırmada, danışanların psikolojik yardım alma sürecinden beklentileri ile psikolojik zihinlilik düzeyleri arasındaki ilişki araştırılmıştır. Araştırma sonucunda yüksek psikolojik zihinlilik düzeyine sahip olan danışanların; psikolojik yardım alma sürecinde daha çok kalıtımcı oldukları ve yardım alma sürecinden daha çok olumlu beklenti içerisinde bulundukları saptanmıştır. Nyklíček ve diğerleri (2010) yapmış oldukları araştırmada farklı sorun alanlarına sahip olan yetişkinlerin, sahip oldukları psikolojik zihinlilik düzeylerinin, onların danışma sürecindeki semptomlarının azaltılmasında ne ölçüde etkili olduğunu incelemiş̧lerdir. Sonuç olarak psikolojik zihinlilik kavramının, içgörü alt boyutu puanındaki yükselmenin, danışanların semptomlarının azalmasıyla ilişkili olduğu görülmüştür. Bunun yanında danışanların psikolojik zihinlilik düzeylerinin, yardım süreci boyunca ilerleyen oturumlarda giderek arttığ 1 tespit edilmiştir. $\mathrm{Bu}$ durum araştırmacılar tarafından; psikolojik zihinlilik kavramının, bir kişilik özelliği olmadığ şeklinde yorumlanmıştır. Ayrıca elde edilen sonuçlar; araştırmacıların, bireylerdeki psikolojik zihinlilik düzeyinin, psikolojik danışma yoluyla yükseltilebileceğini düşünmelerine yol açmıştır.

Alanyazın incelendiğinde psikolojik zihinlilik konusunda, ergenlerle ilgili sınırlı sayıda çalışma yapıldığı görülmektedir (Boylan, 2006; Hatcher, Hatcher, Berlin, Okla ve Richards, 1990; Roxas, 2011; Roxas ve Glenwick, 2014). Boylan (2006) depresyon tanısı almış ergenlerle yapmış olduğu araştırmasında; ergenlerin sahip olduğu psikolojik zihinlilik düzeyinin, onların bilişsel davranışçı terapiden yararlanma oranlarında anlamlı bir fark yaratmadığını tespit etmiştir. Bu 
bağlamda psikolojik zihinlilik kavramının çocuklarda ve ergenlerde varlığının ve ölçülmesinin tartışmalı olduğu ve bu yaş gruplarında yapılmış olan araştırmaların azlığı göz önüne alınarak; Boylan'ın tez çalışmasından elde ettiği bulguların yorumlanması için çocuk ve ergenlerde bulunan psikolojik zihinlilik düzeyi konusunda daha fazla bulgu toplanmasına ihtiyaç olduğu anlaşılmaktadır.

$\mathrm{Bu}$ açıdan bakıldığında, çocuk ve ergenlerdeki psikolojik zihinlilik düzeyinin ölçülmesi hem uygulayıcılar açısından hem de ileride yapılacak olan araştırmalar açısından önemli görünmektedir. Bu bağlamda, bu araştırmanın amacı ergenler üzerinde geçerliği ve güvenirliği sağlanmış bir psikolojik zihinlilik ölçeği geliştirerek uygulayıcıların ve araştırmacıların kullanımına sunmaktır.

\section{Yöntem}

Yapılan araştırma bir ölçek geliştirme çalışmasıdır. Dolayısıyla araştırma, amacına uygun olarak ölçek geliştirme işlemlerini kapsamaktadır. Çalışma dört aşamada gerçekleştirilmiştir. $\mathrm{Bu}$ aşamalar: Ölçek maddelerini belirleme, uzman görüşüne başvurma, ölçeği uygulama, geçerlik ve güvenirliği belirleme olarak adlandırılmıştır.

$\mathrm{Bu}$ bölümde araştırma süreci ile ilgili çalışma grubu, veri toplama araçları, işlem yolu, verilerin toplanması ve verilerin analizi ile ilgili bilgiler yer almaktadır.

\section{Çalışma grubu}

$\mathrm{Bu}$ araştırmada, bir ölçek geliştirilmeye çalışıldığ 1 için ölçeğin geliştirilme sürecinin her bir adımında; Muğla'nın Bodrum ilçesinde eğitim ve öğrenim faaliyetlerine devam etmekte olan ortaöğretim öğrencileri içerisinden, uygun örnekleme yöntemi kullanılarak oluşturulan birbirinden bağımsız 6 farklı çalışma grubu kullanılmıştır. Uygun örnekleme yöntemi: Araştırmacıların çalışmaları için yeterli düzeydeki bir gruba ulaşmak adına kendisine en yakın olan yanıtlayıcılardan başlamasıdır. Bu örnekleme yönteminde amaç maksimum tasarrufu sağlayarak araştırılmak istenen durumun veya örneğin incelenmesidir (Büyüköztürk, KılıçÇakmak, Akgün, Karadeniz ve Demirel, 2016). Bu bağlamda ölçeğin geliştirilme aşamasında 670 kadın ve 584 erkek olmak üzere toplamda 1254 ortaöğretim öğrencisinden oluşturulan, birbirinden bağımsız 6 farklı çalışma grubu kullanılmıştır. Çalışma gruplarını oluşturan ortaöğretim öğrencilerinin yaş aralıkları 14 ila 19 arasındadır $(x=16.25, \mathrm{ss}=1.85)$. Veri toplama sürecindeki çalışma grupları sırasıyla:

\section{1. Çalışma grubu}

Uzman kanısının ardından belirlenen 64 maddelik ölçeğin pilot uygulamasının yapılması amacıyla 30 kişilik öğrenci $(\mathrm{x}=16.28$, ss=1.64) grubu oluşturulmuştur. Uygulama sonrasında öğrencilerin, açık bir şekilde anlaşılmadığını söyledikleri 8 madde üzerinde, Türkçe alan uzmanının da görüşleri alınarak düzeltmeler yapılmıştır.

\section{2. Çalışma grubu}

Ölçeğin faktör yapısını incelemek için yapılan Açımlayıcı Faktör Analizi'nde (AFA), 207 kadın ve 196 erkek olmak üzere toplamda 403 öğrenci $(x=16.03$, ss=1.72) ile çalış1lmıştır. Ölçek, AFA sonucunda araştırmacıların beklediği gibi 4 faktörlü (psikolojik yardım arama, psikolojik ilgi, içgörü ve değişim kapasitesi) bir yapı vermiştir.

\section{3. Çalışma grubu}

Model uyumunu incelemek adına 148 kadın ve 106 erkek olmak üzere toplamda 254 öğrenciden $(\mathrm{x}=16.18, \mathrm{ss}=1.78)$ toplanan veriler üzerinde Doğrulayıcı Faktör Analizi (DFA) yöntemi kullanılmıştır. DFA'dan elde edilen verileri incelendiğinde, AFA sonucunda ulaşılan 4 faktörlü ölçek yapısının doğrulandığı görülmüştür. 


\section{4. Çalışma grubu}

Ölçüt bağıntılı geçerliği incelemek amacıyla 105'i kadın ve 87'si erkek ( $x=16.25$, ss=1.62) toplamda 192 kişilik öğrenci grubu oluşturulmuştur. Ölçüt bağıntılı geçerlik için Toronto Aleksitimi Ölçeği ve Ergenler için Kapsamlı Bilinçli Farkındalık Deneyimleri Envanteri kullanılmıştır. Ergenler için Psikolojik Zihinlilik Ölçeğinin, Toronto Aleksitimi Ölçeği ile negatif; Ergenler için Kapsamlı Bilinçli Farkındalık Deneyimleri Envanteri ile pozitif yönde orta düzeyde ilişkili olduğu sonucuna ulaşılmıştır.

\section{5. Çalışma grubu}

İç tutarlılık ve iki yarı güvenirliği için 182 'si kadın ve 135 'i erkek $(x=15.98$, ss=1.87) olmak üzere toplam 317 kişilik öğrenci grubu oluşturulmuştur. Ergenler için Psikolojik Zihinlilik Ölçeğinin ve alt boyutlarının, yüksek düzeyde iç tutarlılığa ve iki yarı güvenirliğine sahip oldukları saptanmıştır.

\section{6. Çalışma grubu}

Test tekrar test güvenirliği için ilk uygulamadan 60 gün sonra 33'ü kadın ve 25'i erkek ( $\mathrm{x}=16.12$, $\mathrm{ss}=2.05$ ) olmak üzere toplam 58 kişilik öğrenci grubu oluşturulmuştur. Ergenler için Psikolojik Zihinlilik Ölçeğinin ve alt boyutlarının yüksek düzeyde test tekrar test güvenirliği verdiği görülmüştür.

Faktör analizinin yapılabilmesi için örneklemde yer alacak katılımcıların sayısı belirlenirken, geliştirilen ölçekte yer alan madde sayısının 5 veya 10 katı kadar bir değerin örneklem ölçütü olarak belirlenmesi gerekmektedir (Bryman ve Cramer, 2001). Başka bir araştırmacı olan Kline (2014) ise ölçek geliştirme çalışmalarında 200 kişilik bir örneklemin kullanılmasının yeterli ve kabul edilebilir olduğunu belirtmiştir. Hatta Kline, ölçeğin faktör yapısının çok sayıda olmadığı ve açık olduğu araştırmalarda, örneklemin 100 kişiye kadar düşürülebileceğini ileri sürmektedir. Yukarıda belirtildiği üzere araştırmada kullanılan çalışma grupları incelendiğinde; örneklemin, ölçeğin geçerlik ve güvenirlik çalışmalarını yapmak için yeterli düzeyde olduğu görülmektedir.

\section{Veri toplama araçları}

Araştırmada veri toplama araçları olarak, geliştirilmekte olan Ergenler için Psikolojik Zihinlilik Ölçeğinin dışında, Toronto Aleksitimi Ölçeği ve Ergenler için Kapsamlı Bilinçli Farkındalık Deneyimleri Envanteri kullanılmıştır. Araştırmada kullanılan tüm veri toplama araçları için fikir hakkı sahiplerinden e-posta yoluyla kullanım izinleri alınmıştır. Araştırmaya başlanmadan önce alınan tüm bu izinler, Etik Kurul Onayına başvuru yapılırken, başvuru dosyasına eklenmiştir. Etik Kurul Onayının alınmasından itibaren başlayan araştırma süreci boyunca yayın etiğinden kesinlikle taviz verilmemiştir.

Toronto Aleksitimi Ölçeği (TAÖ-20): TAÖ-20, Bagby, Parker ve Taylor (1994) tarafindan, kişilerin duygularını dile getirmek için uygun sözleri bulma konusunda güçlük çekmesi, duygularını yeterince yaşayamaması ve söze dökememesi gibi özelliklerini değerlendirmek için geliştirilmiştir. Ölçeğin Türk kültürüne uyarlanması Güleç ve diğerleri (2009) tarafindan gerçekleştirilmiştir. Toplamda 20 maddeden oluşan ölçek, 5'li Likert tipindedir. Ölçek üç alt boyutlu bir yapıdan oluşmaktadır. TAÖ-20'den toplam puan alınabilmektedir. Ölçekte toplam dokuz tane ters puanlanan madde bulunmaktadır. TAÖ-20'den en düşük 20 puan, en çok ise 100 puan alınmaktadır. Ölçekten alınan puan arttıkça, kişideki aleksitimi düzeyinin de yükseldiği anlaşılmaktadır. Ölçek toplam varyansın \%34.90'ını açıklamaktadır. TAÖ-20'nin genel iç tutarlık katsayısı .78'dir. Alt boyutlarının iç tutarlık katsayıları sırasıyla; duygularını tanıma zorluğu (7 madde) .80; duygularını ifade etme zorluğu (5 madde) .57 ve dişa vuruk düşünme ( 8 madde) .63’tür (Güleç ve diğerleri, 2009). Bu çalışmada, TAÖ-20'nin Cronbach alfa iç tutarlık katsayı ölçeğin tamamında .80; duygularını tanıma zorluğu alt boyutunda .68; duygularını ifade etme zorluğu alt boyutunda .64 ve dişa vuruk düşünme alt boyutunda ise .74 olarak bulunmuştur. 
Ergenler İçin Kapsamlı Bilinçli Farkındalık Deneyimleri Envanteri (EKBFDE): EKBFDE, Johnson, Burke, Brinkman ve Wade (2017) tarafından, kişilerin kasten ve sürekli olarak içinde bulunulan anda kalıp, yargılamaksızın dikkatini vererek geliştirdikleri farkındalık durumunu değerlendirmek için geliştirilmiştir. Ölçeğin Türk kültürüne uyarlaması Kırca (2017) tarafından yapılmıştır. Ölçek toplam 25 madde ve 5'li Likert tipindedir. Ölçeğin sekiz alt boyutu bulunmaktadır. Ölçekten toplam puan alınamamaktadır, her alt boyut kendi içinde değerlendirilmektedir. Ölçekte toplam sekiz tane ters puanlanan madde bulunmaktadır. EKBFDE'nin her bir alt boyutu için elde edilen yüksek puan; kişilerin, o alt boyut için belirlenen özelliğe ne oranda sahip olduğunu gösterir. EKBFDE'nin genel iç tutarlık katsayısı .70'dir. Alt boyutlarının iç tutarlık katsayıları sırasıyla; içsel deneyimin farkındalığı (3 madde) .57; dışsal deneyimin farkındalığı (3 madde) .67; farkındalıkla davranma (3 madde) .66; kabul ve yargılamaksızın yönelim ( 3 madde) .48; merkezsizleşmek ve tepkisizlik ( 3 madde) .60; deneyime açık olma (4 madde) .64; düşüncelerin göreceliliği ( 3 madde) .54 ve içgörülü kavrayış ( 3 madde) .69'dur (Kırca, 2017). Bu çalışma kapsamında ölçeğin Cronbach alfa iç tutarlık katsayı ölçeğin bütünü için .75; içsel deneyimin farkındalığ 1 alt boyutu için .60; dışsal deneyimin farkındalığ 1 alt boyutu için .69; farkındalıkla davranma alt boyutu için .71; kabul ve yargılamaksızın yönelim alt boyutu için .55; merkezsizleşmek ve tepkisizlik alt boyutu için .64; deneyime açık olma alt boyutu için .68; düşüncelerin göreceliliği alt boyutu için .59 ve içgörülü kavrayış alt boyutu için .72 olarak bulunmuştur.

\section{İşlem}

Ergenler için Psikolojik Zihinlilik Ölçeğinin madde havuzunu oluşturmak için psikolojik zihinlilik kavramına dair alanyazın incelenerek 55 maddeden meydana gelen bir madde havuzu ortaya konulmuştur. Madde havuzu ortaya konulduktan sonra ölçeğin ilk formu kapsam ve görünüş geçerliğine uygunluğu açısından beş rehberlik ve psikolojik danışmanlık, bir ölçme ve değerlendirme alan uzmanının ve dilsel olarak anlaşılabilirliğinin incelenmesi amacıyla da bir Türkçe alan uzmanının bilgisine başvurulmuştur. Elde edilen geri bildirimler ve öneriler doğrultusunda; ölçekte yer alan ifadeler gözden geçirilmiş, madde sayısı 64'e çıkarılmış ve ölçeğin uygulanacağ ilk form ortaya çıkmıştır. Ölçeğin pilot uygulaması, bu form ile 30 kişiden oluşan bir örneklem grubu üzerinde yapılmıştır. Pilot uygulama sırasında öğrencilerden anlamakta zorlandıkları maddelerin yanına işaret koymaları istenmiştir. Öğrencilerden alınan geri bildirimler doğrultusunda 8 maddenin anlaşılmasında güçlük olduğu tespit edilmiştir. Bu 8 madde üzerinde bir Türkçe alan uzmanının da görüşleri alınarak düzeltmeler yapılmıştır.

\section{Verilerin toplanması}

Öncelikle çalışmaya başlanabilmesi için araştırmacılar tarafindan Mehmet Akif Ersoy Üniversitesi Girişimsel Olmayan Klinik Araştırmalar Etik Kurulu Başkanlığından, çalışmanın etik olarak uygunluğu açısından onay alınmıştır. Daha sonra çalışmanın Muğla/Bodrum'daki ortaöğretim kurumlarında sağlıklı olarak yürütülebilmesi için Etik Kurul Onayı ile beraber Bodrum İlçe Milli Eğitim Müdürlüğ̈̈’nden gerekli izinler alınmıştır. Verilerin toplanabilmesi için araştırmacılar, her bir çalışma grubu için belirlenmiş olan okullara bizzat gitmiştir. Araştırmacılar verilerin toplanacağı her bir sınıfa ayrı ayrı girmiş, öğrencilere araştırmanın içeriği ve ölçekler ile ilgili gerekli açıklamaları yapmıştır. Öğrencilerden gönüllülüğe esas olarak, araştırmaya katılacaklardan bilgilendirilmiş onam formları imzalı olarak alınmıştır. Ayrıca 18 yaşının altında olan ve çalışmaya katılma konusunda gönüllü olan öğrencilerin velileri ile iletişime geçilmiştir; öğrencilerinin araştırmaya katılmasına izin verdiklerine dair velilerden imzalı olarak bilgilendirilmiş onam formları alınmıştır. Daha sonra ölçeklerin, öğrenciler tarafından doldurulması sağlanmıştır. Her bir çalışma grubu için yapılmış olan uygulamalar sırasıyla: Pilot uygulama için 25 dakika, AFA için 25 dakika, DFA için 10 dakika, ölçüt bağıntılı geçerlik için 30 dakika, iç tutarlık ve iki yarı güvenirliği için 10 dakika, test tekrar test güvenirliği için 10 dakika sürmüştür. Tamamlanan ölçekler incelenmiş ve öğrenciler tarafindan tam olarak doldurulmayan ölçekler çalışma kapsamına alınmamıştır. 


\section{Veri analizi}

Ergenler için Psikolojik Zihinlilik Ölçeğinin son formu 64 maddelidir ve bu 64 maddelik form ile geçerlik ve güvenirlik analizi işlemleri yapılmıştır. Ölçeğin geçerlik ve güvenirlik analizleri için toplanmış olan veriler bilgisayar ortamında SPSS 20.0 programına seriler halinde girilmiştir. Daha sonra eksik veriler tespit edilmiş, uç değerler incelenmiş, normallik ve doğrusallık varsayımlarına bakılmış ve Multicollinearity analizi yapılmıştır. Bu bağlamda veri setinde bulunan ve kabul edilebilir düzeyde olan boşluklara aritmetik ortalama değerler verilerek doldurulmuştur. Daha sonra veri setindeki normalliği etkileyecek seviyede uç değerlere sahip olduklarından dolayı; AFA için olan çalışma grubundan 2 kişinin verileri, DFA için olan çalışma grubundan 4 kişinin verileri, ölçüt bağıntılı geçerlik çalışmaları için oluşturulan çalışma grubundan 3 kişinin verileri ve son olarak güvenirlik analizleri için oluşturulan çalışma grubundan 4 kişinin verileri araştırmadan çıkarılmıştır. Ölçeğin örtük yapısı SPSS 20.0 programı kullanılarak AFA yardımıyla ve model uyumu LISREL 8.7 programı kullanılarak DFA yardımıyla ortaya konulmuştur. DFA için çoklu uyum indekslerinden olan RMSEA, RMR, SRMR, NFI, NNFI, CFI, IFI, RFI, AGFI ve GFI değerlerine bakılmıştır. RMR, RMSEA ve SRMR değerleri için $.05<x<.08$ kabul edilebilir düzey ve $.00<x<.05$ mükemmel uyum düzeyi olarak kabul edilmektedir. NFI, NNFI, CFI, IFI, RFI, AGFI ve GFI değerleri için ise $.90<\mathrm{x}<.95$ kabul edilebilir değer ve $.95<x<1.00$ mükemmel uyum değeri olarak kabul edilmektedir (Cole, 1987, Hu ve Bentler, 1999; Marcoulides ve Schumacker, 2001). DFA sonucu elde edilen Ki-kare ( $\left.X_{2} / \mathrm{sd}\right)$ değeri için $2<X_{2} / \mathrm{sd}<3$ kabul edilebilir sinır olarak ve $0<X_{2} / \mathrm{sd}<2$ ise mükemmel uyum değeri olarak kabul edilmiştir (Kline, 2014; Marcoulides ve Schumacker, 2001; Schumacker ve Lomax, 2016).

\section{Bulgular}

$\mathrm{Bu}$ bölümde, araştırma kapsamında geliştirilmekte olan Ergenler için Psikolojik Zihinlilik Ölçeğinin geçerlik ve güvenirlik çalışmaları yapılmıştır.

\section{Geçerlik çalışmaları}

Ergenler için Psikolojik Zihinlilik Ölçeğinin geçerliğinin belirlenmesi amacıyla yapı geçerliği ve ölçüt bağıntılı geçerlik çalışmaları yapılmıştır.

\section{Yapı geçerliği}

Ergenler için Psikolojik Zihinlilik Ölçeğinin yapı geçerliğinin belirlenmesi amacıyla açımlayıcı ve doğrulayıcı faktör analizi yapılmıştır.

Açımlayıcı faktör analizi: Ergenler için Psikolojik Zihinlilik Ölçeğinin faktör yapısını incelemek adına ilk olarak AFA yapılmıştır. AFA, uzmanların görüşleri neticesinde oluşturulan ölçeğin deneme formunun, 403 kişiden oluşan ikinci çalışma grubuna uygulanması sonucunda elde edilen veriler üzerinde gerçekleştirilmiştir. AFA yapılmadan önce çalışma grubundan elde edilen verilerin AFA için uygunluğuna Kaiser Meyer Olkin (KMO) Katsayısı ve Bartlett Küresellik Testi ile bakılmıştır (Büyüköztürk, 2014). KMO katsayısı, örneklem büyüklüğü açısından faktör analizi için veri yapısının uygunluğunu göstermektedir. KMO katsayısının .60'ın altında yer alması verilerin AFA yapmak için uygun olmadığını; 1.00'e yakın olması ise verilerin AFA için uygun durumda olduğunu göstermektedir (Büyüköztürk, 2014). Bartlett Küresellik Testinin değeri ve anlamlılığına bakarak değişkenlerin birbirleriyle korelasyon gösterip göstermedikleri incelenmektedir. Tablo-1'e bakıldığında Ergenler için Psikolojik Zihinlilik Ölçeğinin KMO değerinin .84 bulunduğu ve Bartlett Küresellik Testinin sonucunun da anlamlı olduğu görülmektedir. 
Tablo 1.

KMO ve Bartlett's Testi Değerleri

\begin{tabular}{lll}
\hline Kaiser-Meyer-Olkin Örneklem Yeterliliği & .844 \\
\hline \multirow{3}{*}{ Bartlett's Test of Sphericity } & Ki-kare Değeri & 3639.133 \\
& Serbestlik Derecesi & 190 \\
& Anlamlılık & .000 \\
\hline
\end{tabular}

Tablo-1'de görüldüğü üzere, elde edilen KMO değeri; örneklem büyüklüğünün ve AFA için kullanılacak olan verilerin uygun ve yeterli düzeyde olduğunu (.84) göstermektedir. Ayrıca Bartlett Küresellik Testi değerlerinin anlamlı $(\mathrm{p}<.01)$ çıkması da veri setindeki değişkenler arasında korelasyonun yeterli olduğunu göstermektedir.

Toplanan verilerin, faktör analizi yapmak için uygun olmasından dolayı; ölçeğin faktör yapısının incelenmesi için AFA, faktörleştirme tekniği için de Temel Bileşenler Analizi (TBA) kullanılmıştır (Kline, 2014). Faktörleştirme tekniği olarak TBA, sık kullanılan ve yorumlanması görece diğer tekniklere göre kolay olan bir istatistik yöntemidir. TBA'da ölçekte yer alması planlanan bir maddenin, tanımlanan bir faktörde kendine yer edinip edinmemesi, o maddenin belirlenen faktörle ilişkisinin göstergesi olan yük değerinin ne derece yüksek olmasına bağlidır. Belirlenmiş olan faktörlerden herhangi biri için yüksek düzeyde yük değeri veren maddelerin, $o$ faktörün tanımladığ1 yapıyı ölçtüğü kabul edilir (Büyüköztürk, 2014). Genellikle maddelerin faktör yük değerlerinin .45 ve üstünde olması istenmektedir ancak yük değeri .32 ve üzerinde yer alan maddelerde ölçekte kalabilir (Kline, 2014; Tabachnick, Fidell ve Ullman, 2007). Bu araştırma kapsamında faktör yükleri .50 ve üzerinde yer alan maddeler ile analize devam edilmiştir. Ayrıca iki faktöre birden yük değeri veren maddeler araştırma kapsamının dışında bırakılmıştır.

Yapılan ilk analizin sonuçlarına bakıldığında ölçeğin, öz-değeri birden büyük olan 20 faktör üzerinde toplandığı görülmektedir. Daha sonra birden fazla faktöre birbirine yakın (fark .10'dan küçük ise) yük değerleri veren (Büyüköztürk, 2014), birden fazla faktöre .32'den fazla yük değeri veren (Costello ve Osborne, 2005) ve madde faktör yük değeri .50'nin altında kalan 25 madde araştırmanın kapsamından çıkartılmıştır. Kalan 39 madde üzerinde Varimaks dik döndürme tekniği ile tekrar analiz yapılmıştır (Büyüköztürk, 2014). Varimaks dik döndürme tekniği sonucunda 19 madde daha araştırma kapsamı dışında bırakılmıştır. Yapılan son analizden sonra ortaya çıkan faktörlerin kapsamında yer alan maddelerin içeriklerine bakılmış ve ölçeğin kavramsal açıdan uygun olabileceği düşünülen dört faktörlü bir yapıda olduğuna karar verilmiştir. Yapılan analizler sonucunda ölçekte yer alan madde sayısı 20'ye düşmüştür. Şekil-1'de görülen, analizler sonunda ulaşılan öz-değer grafiği incelenmiş ve elde edilen dört faktörün yorumlanabilir düzeyde olduğu anlaşılmıştır.

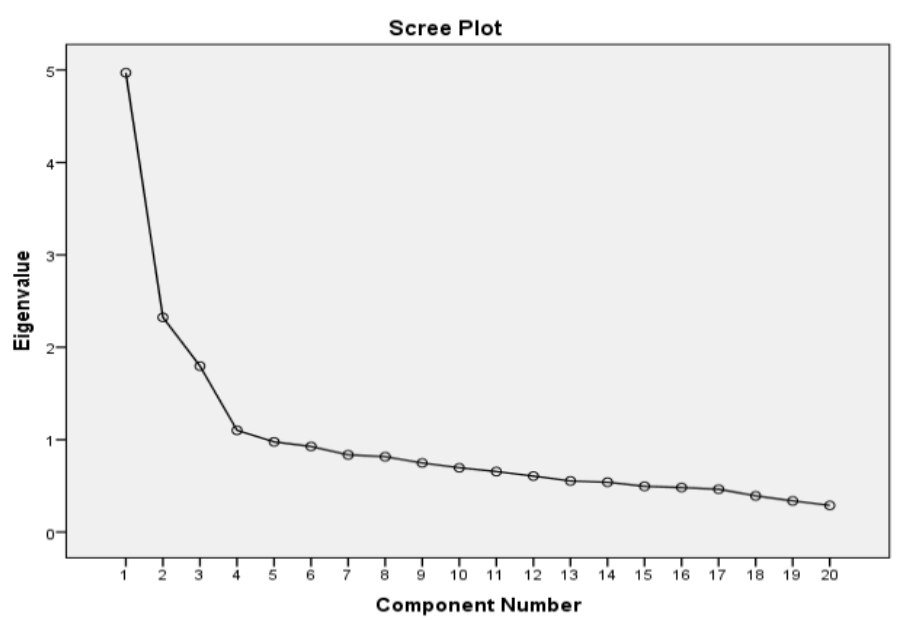

Şekil 1. Açımlayıcı Faktör Analizi Öz-değer Grafiği (Scree Plot) 
AFA sonucunda ulaşılan faktörlerin öz-değerlerini gösteren Şekil-1'e bakıldığında, hızlı düşüşlerin yaşandığı dört kayda değer faktörün olduğu görülmektedir. Şekil-1 incelendiğinde birinci faktörden sonra çok hızlı bir düşüşün yaşandığı; ikinci, üçüncü ve dördüncü faktörlerden sonra ise daha az ancak önemli düşüşlerin yaşandığ1 görülmektedir. Sonraki faktörlere bakıldığında grafiğin yatay şekilde devam ettiği ve önemli bir düşüşün yaşanmadığ 1 anlaşılmaktadır. Bu bağlamda ölçeğin dört faktörlü bir yapıda olabileceği düşünülmektedir.

Yukarıda belirtilen ölçütlere uyan 20 madde ve bu maddelerin içerisinde yer aldığı dört faktör bulunmuştur. Her bir faktörün kapsamında yer alan maddeler, içerikleri göz önüne alınarak incelenmiş ve maddelerin içerikleri dikkate alınarak faktörler adlandırılmıştır. Bu dört faktörün birincisi 1., 2., 4., 6. ve 10. maddelerden oluşan "psikolojik yardım arama" alt ölçeğidir. İkincisi 26., 27., 28., 29. ve 31. maddelerden oluşan "psikolojik ilgi” alt ölçeğidir. Üçüncüsü 39., 41., 42., 44. ve 45. maddelerden oluşan "içgörü" alt ölçeğidir. Dördüncüsü ise 50., 55., 56., 57. ve 58. maddelerden oluşan "değişim kapasitesi" alt ölçeğidir. Tablo-2'de alt ölçeklere göre maddeler, faktör yükleri, alt ölçeklerin açıkladığ 1 varyanslar ve madde analizleri verilmiştir.

Tablo 2.

Ergenler için Psikolojik Zihinlilik Ölçeğinin Madde Faktör Yükleri, Alt Ölçeklerin Açıkladığı Varyanslar ve Madde Analizleri

\begin{tabular}{|c|c|c|c|c|c|}
\hline Madde & 1.Faktör & 2.Faktör & 3.Faktör & 4.Faktör & $\begin{array}{c}\text { Madde Toplam } \\
\text { Korelasyonu }\end{array}$ \\
\hline Madde 1 & .744 & & & & .530 \\
\hline Madde 2 & .798 & & & & .536 \\
\hline Madde 4 & .567 & & & & .466 \\
\hline Madde 6 & .614 & & & & .448 \\
\hline Madde 10 & .741 & & & & .519 \\
\hline Madde 26 & & .779 & & & .507 \\
\hline Madde 27 & & .654 & & & .582 \\
\hline Madde 28 & & .687 & & & .467 \\
\hline Madde 29 & & .581 & & & .426 \\
\hline Madde 31 & & .514 & & & .445 \\
\hline Madde 39 & & & .652 & & .611 \\
\hline Madde 41 & & & .715 & & .610 \\
\hline Madde 42 & & & .676 & & .553 \\
\hline Madde 44 & & & .714 & & .587 \\
\hline Madde 45 & & & .621 & & .584 \\
\hline Madde 50 & & & & .530 & .459 \\
\hline Madde 55 & & & & .822 & .496 \\
\hline Madde 56 & & & & .823 & .487 \\
\hline Madde 57 & & & & .598 & .472 \\
\hline Madde 58 & & & & .549 & .442 \\
\hline Açıklanan Varyans: & $\% 14.53$ & $\% 13.65$ & $\% 11.71$ & $\% 11.05$ & \\
\hline Toplam Varyans: & $\% 50.95$ & & & & \\
\hline
\end{tabular}

Tablo-2 incelendiğinde, AFA sonucunda Faktör-1 (psikolojik yardım arama) \%14.53, Faktör-2 (psikolojik ilgi) \%13.65, Faktör-3 (içgörü) \%11.71 ve Faktör-4 (değişim kapasitesi) $\% 11.05$ olmak üzere toplam varyansın \%50.95'ini açılayan dört faktörlü bir yapı elde edildiği görülmektedir.

Ölçeğin geneline ilişkin madde faktör yük değerlerinin .51 ila .82 aralığında değiştiği görülmektedir. Ölçek geliştirme ve uyarlama süreçlerinde madde faktör yük değerlerinin alt sınırının .32 olması gerektiği belirtilmektedir (Tabachnick ve diğerleri, 2007). Ulaşılan sonuçlar 
göz önüne alındığında ölçeğin dört faktörden oluşan yapısının madde faktör yük değerlerinin kabul edilebilir düzeyde olduğu söylenebilir (Hair, Black, Babin, Anderson ve Tatham, 2006).

Ergenler için Psikolojik Zihinlilik Ölçeğinin madde geçerliğini incelemek amacıyla düzeltilmiş madde toplam korelasyon değerlerine bakılmıştır. Ölçekte yer alan 20 maddenin, madde toplam korelasyon değerlerinin .42 ila .61 aralığında değiştiği görülmektedir. Madde toplam korelasyon değerleri yorumlanırken .30 ve üzeri değere sahip olan maddeler ölçmeyi amaçlanan özelliği ayırt etmek için yeterli ve kabul edilebilirdir. Ayrıca Tablo-2 incelendiğinde madde toplam korelasyon değeri ile ölçeğin toplamının da uyumlu olduğu anlaşılmaktadır (Büyüköztürk, 2014; Field, 2009). Tablo-2'deki değerler göz önüne alındığında Ergenler için Psikolojik Zihinlilik Ölçeğini oluşturan tüm maddelerin, ölçek toplam puanı ile orta veya yüksek düzeyde ilişki içerisinde olduğu ve madde geçerliğini sağladıkları söylenebilir.

Tablo-3'de Ergenler için Psikolojik Zihinlilik Ölçeğinin alt boyutları arasındaki ilişkiyi ortaya koymak için alt boyutlar arasındaki korelasyonlar incelenmiştir. Alt boyutlar arasındaki korelasyon katsayılarının çoklu bağıntı (Multicollinearity) problemi yaratmaması için .90 ve üzerinde bulunmaması gerekmektedir (Akbulut, 2010; Field, 2009; Pallant, 2005).

Tablo 3.

Ergenler için Psikolojik Zihinlilik Ölçeğinin Alt Boyutları Arasındaki Korelasyonlar

\begin{tabular}{lccccc}
\hline & 1 & 2 & 3 & 4 & $\begin{array}{c}\text { Toplam } \\
\text { EPZÖ }\end{array}$ \\
\hline 1.Psikolojik Yardım Arama & 1 & & & & \\
2.Psikolojik İlgi & $.357^{* *}$ & 1 & & & \\
3.İçgörü & $.433^{* *}$ & $.570^{* *}$ & 1 & & \\
4.Değişim Kapasitesi & $.358^{* *}$ & $.342^{* *}$ & $.380^{* *}$ & 1 & \\
Toplam EPZÖ & $.694^{* *}$ & $.706^{* *}$ & $.795^{* *}$ & $.464^{* *}$ & 1 \\
\hline$* * \mathrm{p}<.01, * \mathrm{p}<.05$ & & & & &
\end{tabular}

Tablo 3'de Ergenler için Psikolojik Zihinlilik Ölçeğinin alt boyutlarının birbirleriyle ve alt boyutların, ölçeğin toplam puanıyla arasındaki korelasyon değerleri görülmektedir. Ulaşılan değerler, ölçeğin dört alt boyutunun kendi aralarında ve ölçeğin toplam puanı ile anlamlı düzeyde ilişkili bulunduğunu ve çoklu bağıntı probleminin olmadığını ortaya koymaktadır.

Doğrulayıcı faktör analizi: AFA işlemi sonucunda ulaşılan dört faktörlü ölçek yapısının, yapısal geçerliğinin sınanması amacıyla belirtilen yapıya ait dört faktörlü model, DFA ile test edilmiştir. Bu amaçla Lisrel 8.7 programı kullanılmıştır. DFA kuramsal alt yapıdan destek alınarak birçok değişkenden oluşturulan faktörlerin, gerçek verilerle ne düzeyde uyum gösterdiğini değerlendirmeyi amaçlayan bir analizdir. DFA ile faktörler arasındaki ilişkilere dair ileri sürülen modelle, gözlenen verilerin ne oranda uyuştuğuna yönelik istatistikî verilere ulaşılabilir (Sümer, 2000). DFA, Yapısal Eşitlik Modeli'nin (YEM) özel olarak kurgulanmış bir biçimidir (Fayers ve Hand, 1997) ve ölçeğin yapı geçerliğinin ortaya konması adına kanıt sunar (Lewis, Francis, Shevlin ve Forrest, 2002; McIntire ve Miller, 2005).

Ergenler için Psikolojik Zihinlilik Ölçeğinin, AFA sonucu oluşan 20 madde ve dört faktörlü yapısının sınanmasına ilişkin gerçekleştirilen DFA'nın bulguları Şekil-2'de sunulmuştur. 


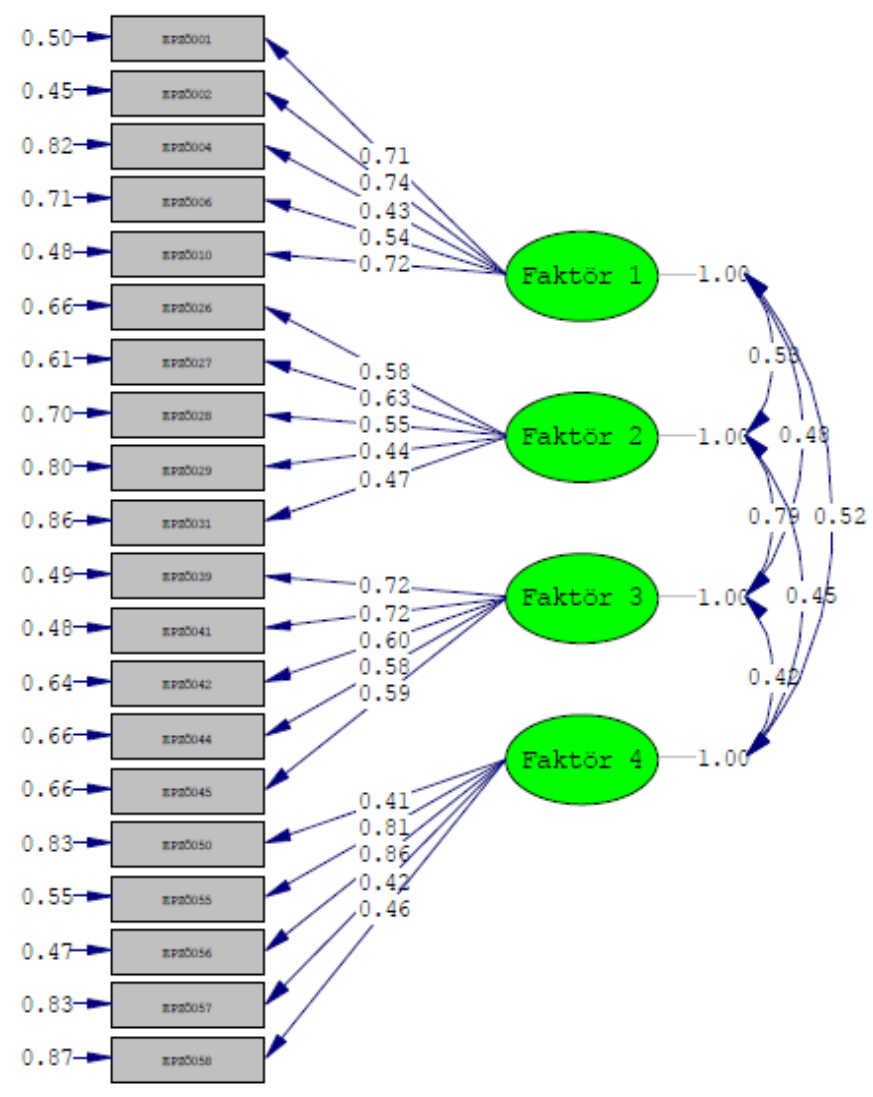

Chi-Square=248.91, df=164, P-value=0.00000, RMSEA=0.045

Şekil 2. Ergenler için Psikolojik Zihinlilik Ölçeği DFA Sonuçları

Şekil-2 incelendiğinde, 20 madde ve dört alt faktörden oluşan Ergenler için Psikolojik Zihinlilik Ölçeğinin uyum indekslerinin anlamlı olduğu görülmektedir $\left(X_{2}=248.91, \mathrm{sd}=164\right.$, $\mathrm{p}=.00, X_{2} / \mathrm{sd}=1.51$ ). Uyum indeksi değerleri ise $\mathrm{RMSEA}=.045, \mathrm{RMR}=.075, \mathrm{SRMR}=.057$, $\mathrm{NFI}=.90, \mathrm{NNFI}=.96, \mathrm{CFI}=.96, \mathrm{IFI}=.96, \mathrm{RFI}=.91, \mathrm{AGFI}=.89, \mathrm{GFI}=.91$ olarak bulunmuştur. DFA sonucunda ulaşılan uyum indeks değerleri, geliştirilen ölçeğin model uyumunun kabul edilebilir düzeyde olduğu şeklinde yorumlanabilir (Kline, 2014; Marcoulides ve Schumacker, 2001; Schumacker ve Lomax, 2016). Yapılan işlemlerden sonra ortaya çıkan değerlerin kabul edilebilir olmasından dolayı hiçbir modifikasyon önerisi uygulanmamıştır. Daha sonra maddeler arasındaki $t$ değerleri kontrol edilmiştir. Yapılan kontrol sonucunda $t$ değerleri ile ilgili herhangi bir kırmızı ok bulunmamıştır. Bu durum ölçeği oluşturan tüm maddelerin .05 düzeyinde anlamlı olduğunu göstermektedir (Seçer, 2018).

Şekil-2'ye bakıldığında ölçeğin Faktör-1'e ait standartlaştırılmış faktör yüklerinin .43 ila .74, Faktör-2'ye ait standartlaştırılmış faktör yüklerinin .44 ila .63, Faktör-3'e ait standartlaştırılmış faktör yüklerinin .58 ila .72 ve Faktör-4'e ait standartlaştırılmış faktör yüklerinin ise .41 ila .86 aralığında değişmekte olduğu görülmektedir. Ayrıca tüm maddelerin hata varyanslarının referans değerden $(x<.90)$ düşük olduğu söylenebilir (Çokluk, Şekercioğlu ve Büyüköztürk, 2014). DFA'dan elde edilen bulgular doğrultusunda Ergenler için Psikolojik Zihinlilik Ölçeğinin model uyumunun kabul edilebilir değerlere sahip olduğu söylenebilir.

\section{Ölçüt bağıntılı geçerlik}

Ergenler için Psikolojik Zihinlilik Ölçeğinin ölçüt bağıntılı geçerliğini incelemek adına Toronto Aleksitimi Ölçeği ve Ergenler için Kapsamlı Bilinçli Farkındalık Deneyimleri Envanteri arasındaki ilişkilere bakılmıştır ve ulaşılan sonuçlar Tablo-4'de sunulmuştur. 
Tablo 4.

Ergenler için Psikolojik Zihinlilik Ölçeğinin Ölçüt Bağıntılı Geçerliğine İlişkin Bulgular

\begin{tabular}{|c|c|c|c|c|c|}
\hline & $\begin{array}{l}\text { Toplam } \\
\text { EPZÖ }\end{array}$ & $\begin{array}{l}\text { Yardım } \\
\text { Arama }\end{array}$ & $\begin{array}{l}\text { Psikolojik } \\
\text { İlgi }\end{array}$ & İçgörü & $\begin{array}{c}\text { Değişim } \\
\text { Kapasites }\end{array}$ \\
\hline 1.Toronto Aleksitimi Ölçeği & $-.278 * *$ & $-.254 * *$ & $-.266 * *$ & $-.284 * *$ & $-.441 * *$ \\
\hline \multicolumn{6}{|c|}{ 2.Ergenler için Kapsamlı Bilinçli Farkındalık Deneyimleri Envanteri } \\
\hline $\begin{array}{l}\text { 2a.İçsel Deneyimin } \\
\text { Farkındalığ Boyutu }\end{array}$ & $.394 * *$ & $.332 * *$ & $.484 * *$ & $.426 * *$ & $.317 * *$ \\
\hline $\begin{array}{l}\text { 2b.Dışsal Deneyimin } \\
\text { Farkındalığı Boyutu }\end{array}$ & $.386 * *$ & $.312 * *$ & $.425 * *$ & $.412 * *$ & $.314 * *$ \\
\hline $\begin{array}{l}\text { 2c.Farkındalıkla Davranma } \\
\text { Boyutu }\end{array}$ & $.275^{* *}$ & $.251 * *$ & $.287 * *$ & $.266^{* *}$ & $.392 * *$ \\
\hline $\begin{array}{l}\text { 2d.Kabul ve } \\
\text { Yargılamaksızın Yönelim }\end{array}$ & $.245^{* *}$ & $.262 * *$ & $.252 * *$ & $.234 * *$ & $.273 * *$ \\
\hline $\begin{array}{l}\text { 2e.Merkezsizleşmek ve } \\
\text { Tepkisizlik Boyutu }\end{array}$ & $.344 * *$ & $.259 * *$ & $.388 * *$ & $.376 * *$ & $.265 * *$ \\
\hline $\begin{array}{l}\text { 2f. Deneyime Açık Olma } \\
\text { Boyutu }\end{array}$ & $.264 * *$ & $.239 * *$ & $.284 * *$ & $.278^{* *}$ & $.341 * *$ \\
\hline $\begin{array}{l}\text { 2g.Düşüncelerin Göreceliği } \\
\text { Boyutu }\end{array}$ & $.253 * *$ & $.287 * *$ & $.373 * *$ & $.346^{* *}$ & $.264 * *$ \\
\hline 2h.İçgörülü Kavrayış & $.232 * *$ & $.241 * *$ & $.263 * *$ & $.324 * *$ & $.248 * *$ \\
\hline
\end{tabular}

$* * \mathrm{p}<.01, * \mathrm{p}<.05$

Tablo 4 incelendiğinde, Ergenler için Psikolojik Zihinlilik Ölçeğinin; Toronto Aleksitimi Ölçeği ile negatif ve Ergenler için Kapsamlı Bilinçli Farkındalık Deneyimleri Envanterinin alt boyutları ile pozitif yönde orta düzeyde korelâsyona sahip olduğu görülmektedir. Ulaşılan bulgular göz önüne alındığında Ergenler için Psikolojik Zihinlilik Ölçeğinin ölçüt bağıntılı geçerliğinin sağlandığı söylenebilir.

\section{Güvenirlik çalıșmaları}

Ergenler için Psikolojik Zihinlilik Ölçeğinin güvenirliğini saptamak amacıyla Cronbach alfa iç tutarlık, Spearman Brown iki yarı ve test-tekrar test güvenirlik analizi yöntemleri uygulanmıştır. Ulaşılan sonuçlar Tablo-5'te sunulmuştur.

Tablo 5.

Ergenler için Psikolojik Zihinlilik Ölçeğinin İç Tutarlık, İki Yarı Güvenirlik ve Test-Tekrar Test Yöntemiyle Hesaplanan Güvenirlik Katsayıları

\begin{tabular}{lccc}
\hline Boyutlar & İç Tutarlılık & $\begin{array}{c}\text { İki Yarı } \\
\text { Güvenirliği }\end{array}$ & Test-Tekrar Test \\
\hline Toplam EPZÖ & .848 & .836 & .847 \\
Psikolojik Yardım Arama & .814 & .810 & .835 \\
Psikolojik İlgi & .852 & .813 & .843 \\
İçgörü & .840 & .804 & .836 \\
Değişim Kapasitesi & .741 & .753 & .722 \\
\hline
\end{tabular}

Ergenler için Psikolojik Zihinlilik Ölçeğinin güvenirliğinin tespit edilmesi amacıyla yapılan; Cronbach alfa iç tutarlık, Spearman Brown iki yarı ve test-tekrar test güvenirliği analizlerinde, ölçeğin tamamı ve alt faktörleri için tespit edilen güvenirlik değerlerinin .72 ila .85 
arasında değiştiği görülmektedir. Ölçek geliştirme ve uyarlama araştırmalarında .70 ve üzeri güvenirlik değerine sahip olan ölçekler güvenilir olarak kabul edilmektedir (Landis ve Koch, 1977; Robinson, Shaver ve Wrightsman, 1991). Bu bağlamda Ergenler için Psikolojik Zihinlilik Ölçeğinin tamamının ve alt faktörlerinin, Tablo-5'deki değerler göz önüne alındığında; kabul edilebilir düzeyde iç tutarlık, iki yarı ve test-tekrar test güvenirlik değerlerine sahip olduğu söylenebilir.

\section{Tartışma, Sonuç ve Öneriler}

Ergenlere etkili psikolojik yardım hizmeti sunulabilmesi için onların ne ölçüde psikolojik zihinliliğe sahip olduklarının bilinmesi büyük önem arz etmektedir. Ergenlerin psikolojik zihinliliklerini meydana getiren; psikolojik yardım arama, psikolojik ilgi, içgörü ve değişim kapasitesi gibi özelliklerinin tespit edilmesi ve geliştirilmesi için ölçülmesi önem kazanmaktadır. $\mathrm{Bu}$ şekilde ergenlerin psikolojik zihinlilik düzeylerini etkilediği öngörülen değişkenlerin ele alınarak incelenmesi ve önleyici çalışmaların içeriklerinin bu bağlamda oluşturulmasının önü açılacaktır. Ancak alanyazın incelendiğinde Türkiye'de ergenlerin psikolojik zihinlilik düzeylerinin ölçülmesi için geliştirilmiş veya yabancı literatürden kültürümüze uyarlanmış bir ölçme aracı bulunamamıştır. Bu çalışma kapsamında alanyazındaki bu boşluğun doldurulmasına çalışılmıştır. $\mathrm{Bu}$ amaçla araştırma sürecinde Ergenler için Psikolojik Zihinlilik Ölçeği geliştirilmiş, geçerlik ve güvenirlik analizleri yapılmıştır.

Ergenler için Psikolojik Zihinlilik Ölçeğinin geliştirilmesi sürecinde ilgili alanyazın taranmış ve alanyazın ışığında ölçeğin muhtemel alt boyutları belirlenmiş̧ir. Araştırmacılar tarafından ölçeğin muhtemel alt boyutları dikkate alınarak, Ergenler için Psikolojik Zihinlilik Ölçeğinde yer alabileceği düşünülen maddelerin olduğu bir havuz oluşturulmuştur. Oluşturulan madde havuzu, ilgili alan uzmanlarının görüşleri ve düzeltme önerileri alınarak tekrar gözden geçirilmiştir. Son şekli verilen maddelerin yer aldığ gerçekleştirilmiştir. Pilot uygulama ile maddelerin anlaşılabilirliği ve uyumları kontrol edilmiştir. Pilot uygulama sonrası, öğrencilerin geri bildirimleri dikkate alınarak, anlaşılması güç olan maddeler üzerinde bir dil bilimci yardımıyla düzeltmeler yapılmıştır. Başlangıçta 55 maddeden oluşan madde havuzu, bu düzetmeler sonrasında 64 maddeye çıkarılmıştır. Pilot uygulama sonrasında ortaya çıkan bu 64 maddelik son form öğrencilere uygulanmıştır. Elde edilen verilere, Ergenler için Psikolojik Zihinlilik Ölçeğinin kaç faktörlü olacağının belirlenmesi amacıyla AFA yapılmıştır. AFA'dan sonra toplam varyansın \%50.95'ini açıklayan dört faktörlü bir ölçek yapısına ulaşılmıştır (Tablo 2). Kline (2014) kitabında, geliştirilen veya uyarlanan ölçek çalışmalarında açıklanan varyansın en az \%40 olmasının gerektiğini belirtmiştir. Bu bilgi göz önüne alındığında AFA sonucu ulaşılan varyans değerinin, ergenler için geliştirilen psikolojik zihinlilik ölçeğinin faktör yapısına karar vermek için yeterli düzeyde olduğunu göstermektedir.

AFA sonucunda ulaşılan faktör yapısının model uyumu DFA yardımıyla incelenmiştir (Şekil 2). Elde edilen sonuçlar, Ergenler için Psikolojik Zihinlilik Ölçeğinin model uyum indekslerinin kabul edilebilir düzeyde olduğunu göstermiştir $\left(X_{2} / \mathrm{sd}=1.51\right.$, RMSEA $=.045$, $\mathrm{RMR}=.075, \mathrm{SRMR}=.057, \mathrm{NFI}=.90, \mathrm{NNFI}=.96, \mathrm{CFI}=.96, \mathrm{IFI}=.96, \mathrm{RFI}=.91, \mathrm{AGFI}=.89, \mathrm{GFI}=.91)$. DFA sonucunda ulaşılan uyum indeks değerleri, geliştirilen Ergenler için Psikolojik Zihinlilik Ölçeğinin model uyumunun kabul edilebilir düzeyde olduğu şeklinde yorumlanabilir (Kline, 2014; Marcoulides ve Schumacker, 2001; Schumacker ve Lomax, 2016). Ergenler için Psikolojik Zihinlilik Ölçeğinin model uyumunun sağlanmasının ardından ulaşılan dört faktörlü yapı, kuramsal görüşler ve ilgili alanyazın ışı̆̆ında; psikolojik yardım arama (5 madde), psikolojik ilgi (5 madde), içgörü (5 madde) ve değişim kapasitesi (5 madde) şeklinde isimlendirilmiştir.

Her bir alt ölçek kendi içerisinde ilgili özelliğin yüksek olduğunu göstermekle beraber ölçekten toplam puan alınabilmektedir. Ergenler için Psikolojik Zihinlilik Ölçeği 5'i ters madde olmak üzere toplamda 20 maddeden oluşmaktadır. Ergenler için Psikolojik Zihinlilik Ölçeği; (1)Hiç uygun değil, (2)Çok az uygun, (3)Kısmen uygun, (4)Oldukça uygun ve (5)Tamamen uygun şeklinde sıralanan 5'li Likert tipindedir. Bundan dolayı ölçekten en az 20, en çok da 100 puan alınabilmektedir. Ölçekten alınan puanın yükselmesi ergende psikolojik zihinlilik düzeyinin arttığına işaret etmektedir. 
Ergenler için Psikolojik Zihinlilik Ölçeğinin ölçüt bağıntılı geçerliğini incelemek amacıyla Toronto Aleksitimi Ölçeği ve Ergenler için Kapsamlı Bilinçli Farkındalık Deneyimleri Envanteri kullanılmıştır. Elde edilen bulgular sonucunda Ergenler için Psikolojik Zihinlilik Ölçeğinin, Toronto Aleksitimi Ölçeği ile negatif yönde anlamlı ilişki içerisinde olduğu tespit edilmiştir. Ayrıca Ergenler için Psikolojik Zihinlilik Ölçeğinin, Ergenler için Kapsamlı Bilinçli Farkındalık Deneyimleri Envanterinin alt boyutları olan içsel deneyimin farkındalığı, dışsal deneyimin farkındalığı, farkındalıkla davranma, kabul ve yargılamaksızın yönelim, merkezsizleşmek ve tepkisizlik, deneyime açık olma, düşüncelerin göreceliği ve içgörülü kavrayış ile pozitif yönde anlamlı ilişki içerisinde olduğu saptanmıştır (Tablo-4). Ulaşılan bu bulgular neticesinde ergenlerdeki aleksitimi düzeyi ile psikolojik zihinlilik düzeylerinin negatif yönde; ergenlerdeki bilinçli farkındalık düzeyi ile psikolojik zihinlilik düzeylerinin ise pozitif yönde ilişkili olduğu söylenebilir. Psikolojik zihinliliğin, bireyin kendisinin ve diğerlerinin davranışları altında yatan nedenleri anlamasına katkı sağlayan bir çeşit ilgi ve yetenek olduğu düşünüldüğünde; kendisinin ve diğer insanların hislerini algılama yetisinden yoksunluk olarak tanımlanan aleksitimi ile negatif; dikkatli bir şekilde kendinde ve etrafında gerçekleşenleri oldukları gibi gözlemlemek ve fark etmek olarak tanımlanan bilinçli farkındalık ile pozitif yönde ilişkili olması araştırmacılar tarafından beklenen bir durumdur. $\mathrm{Bu}$ noktadan hareketle ergenlerdeki psikolojik zihinlilik kavramı hakkında yapılması planlanan araştırmalarda bu bulguların da göz önüne alınmasının faydalı olacağı düşünülmektedir.

Ergenler için Psikolojik Zihinlilik Ölçeğinin güvenirliğinin belirlenmesi amacıyla ölçeğin bütününe ve alt boyutlarına; Cronbach alfa iç tutarlılık güvenirliği, iki yarı test güvenirliği ve testtekrar test güvenirliği analiz yöntemleri uygulanmıştır. Yapılan işlemler sonucunda elde edilen bulgulara bakıldığında Ergenler için Psikolojik Zihinlilik Ölçeğinin bütünü ve alt boyutlarının; Cronbach Alfa iç tutarlılık güvenirliğini, iki yarı test güvenirliğini ve test-tekrar test güvenirliğini sağladığı görülmektedir (Tablo-5). Ölçeklerin geliştirilmesi ve uyarlanması çalışmalarında ölçeğin güvenilir olarak kabul edilmesi için .70 ve üstünde bir güvenirlik değerini sağlaması yeterlidir (Fraenkel, Wallend ve Hyun, 2012; Landis ve Koch, 1977; Nunnally ve Bernstein, 1994; Robinson ve diğerleri, 1991).

$\mathrm{Bu}$ araştırma içerisinde geliştirilen Ergenler için Psikolojik Zihinlilik Ölçeğinin geçerlik ve güvenirlik analizleri sadece Muğla'nın Bodrum ilçesindeki ortaöğrenim kurumlarında eğitim ve öğrenim gören, 14-19 yaş aralığında yer alan öğrencilerle gerçekleştirilmiştir. Bu bakımdan Muğla ilinden farklı illerde bulunan ortaöğretim öğrencileri, ayrıca ilkokul ve ortaokul kademelerinde bulunan diğer öğrenciler üzerinde Ergenler için Psikolojik Zihinlilik Ölçeğinin geçerlik ve güvenirlik çalışmalarının yapılmaması, önemli bir sınırlılık olarak gösterilebilir. Bu açıdan bakıldığında daha sonra yapılması planlanan araştırmalarda ölçeğin geçerlik ve güvenirlik çalışmalarının farklı farklı illerde ve ayrıca ilkokul ve ortaokul kademesi öğrencilerini de kapsayacak şekilde planlanması önerilebilir. Bu önerilere ek olarak Ergenler için Psikolojik Zihinlilik Ölçeğinin, psikolojik zihinlilikle ilişkisi olduğu düşünülen demografik (cinsiyet, sınıf düzeyi, SED vb.) ve sürekli değişkenlerle (empati, psikolojik dayanıklılık, yaşam doyumu vb.) ilişkisinin incelendiği araştırmalarda kullanılması; hem ölçeğin geçerlik ve güvenirlik bulgularına hem de psikolojik zihinlilik kavramının açıklanma sürecine katkı sağlayacağı öngörülmektedir. Ayrıca ölçüt bağıntılı geçerlik için yapılan analiz işlemlerinde Ergenler için Psikolojik Zihinlilik Ölçeği ile aleksitimi ve bilinçli farkındalık ölçekleri arasında anlamlı ilişkiler olduğu tespit edildiği için aleksitimi ve bilinçli farkındalık değişkenlerinin ergenlerin psikolojik zihinlilikleri üzerindeki olası etkilerini araştıran çalışmaların planlanması önerilebilir.

\section{Etik Kurul Onay Bilgileri}

Etik değerlendirmeyi yapan kurul adı: Burdur Mehmet Akif Ersoy Üniversitesi Girişimsel Olmayan Klinik Araştırmalar Etik Kurulu

Etik değerlendirme kararının tarihi: 15.04.2020

Etik değerlendirme belgesi sayı numarası: GO 2020/88 


\section{Kaynaklar}

Akbulut, Y. (2010). Sosyal bilimlerde SPSS uygulamaları (1.Basım). İstanbul: İdeal Kültür Yayıncilik.

Appelbaum, S. A. (1973). Psychological-mindedness: Word, concept and essence. International Journal of Psychoanalysis, 54(1), 35-46.

Asay, T. R. ve Lambert, M. J. (1999). The empirical case of the common factors in psychotherapy: quantitative findings. M. A. Hubble, B. L. Duncan ve S. D. Miller (Yay. haz.), The Heart And Soul of Change: What Works in Therapy içinde (ss. 23-55). Washington DC: American Psychological Association.

Bagby, R. M., Parker, J. D. A. ve Taylor, G. J. (1994). The twenty-item Toronto alexithymia scale-I. Item selection and cross validation of the factor structure. Journal of Psychosomatic Research, 38(1), 23-32. Doi:10.1016/0022-3999(94)90005-1

Beitel, M. ve Cecero, J. J. (2003). Predicting psychological mindedness from personality style and attachment security. Journal of Clinical Psychology, 59(1), 163-172.

Beitel, M., Ferrer, E. ve Cecero, J. J. (2004). Psychological mindedness and cognitive style. Journal of Clinical Psychology, 60(6), 567-582. Doi:10.1002/jclp.10258

Beitel, M., Hutz, A., Sheffield, K. M., Gunn, C., Cecero, J. J. ve Barry, D. T. (2009). Do psychologically-minded clients expect more from counselling? Psychology and Psychotherapy: Theory, Research and Practice, 82(4), 369-383.

Beutler, L. E., Malik, M., Alimohammed, S., Harwood, M. T., Talebi, H., Noble, S. ve Wong, E. (2004). Therapist variables. M. J. Lambert (Yay. haz.). Bergin and Garfield's Handbook of Psychotherapy and Behavior Change (5th ed.) içinde (ss. 227-306). New York: Wiley.

Boylan, M. B. (2006). Psychological mindedness as a predictor of treatment outcome with depressed adolescents (Unpublished doctoral thesis). University of Pittsburgh, Pennsylvania.

Bryman, A. ve Cramer, D. (2001). Quantitative data analysis with SPSS Release 10 for Windows: A guide for social scientists. London: Routledge. Doi:10.4324/9780203471548

Büyüköztürk, Ş. (2014). Sosyal bilimler için veri analizi el kitabı (19.Basım). Ankara: Pegem Akademi Yayıncilik.

Büyüköztürk, Ş., Kılıç-Çakmak, E., Akgün, Ö. E., Karadeniz, Ş. ve Demirel, F. (2016). Bilimsel araştırma yöntemleri (21.Basım). Ankara: Pegem Yayınları.

Clarkin, J. F. ve Levy, K. N. (2004). The influence of client variables on psychotherapy. M. J. Lambert (Yay. haz.), Bergin and Garfield's Handbook of Psychotherapy And Behavior Change (5th ed.) içinde (ss. 194-226). New York: Wiley.

Cole, D. A. (1987). Utility of confirmatory factor analysis in test validation research. Journal of Consulting and Clinical Psychology, 55(4), 584-594. Doi:10.1037/0022-006X.55.4.584

Conte, H. R., Buckley, P., Picard, S. ve Karasu, T. B. (1995). Relationships between psychological mindedness and personality traits and ego functioning: Validity studies. Comprehensive Psychiatry, 36(1), 11-17. Doi:10.1016/0010-440X(95)90093-B

Conte, H. R., Ratto, R. ve Karasu, T. B. (1996). The psychological mindedness scale. Factor structure and relationship to outcome of psychotherapy. The Journal of Psychotherapy Practice and Research, 5(3), 250-259.

Costello, A. B. ve Osborne, J. (2005). Best practices in exploratory factor analysis: Four recommendations for getting the most from your analysis. Practical Assessment, Research, and Evaluation, 10(1), 1-9. Doi:10.7275/jyj1-4868

Çokluk, Ö., Şekercioğlu, G. ve Büyüköztürk, Ş. (2014). Sosyal bilimler için çok değiş̧kenli istatistik SPSS ve LISREL uygulamalarn (3.Basım). Ankara: Pegem Akademi.

Denizli, S. (2010). Danışanların algıladıkları terapötik çalışma ve oturum etkisi düzeylerinin bazı değişkenlere göre yordanması: Ege Üniversite örneği (Yayımlanmamış doktora tezi). Ege Üniversitesi, Sosyal Bilimler Enstitüsü, İzmir.

Denizli, S., Lüleci, B. ve Meydan, B. (2015). Psikolojik düşüncelilik kavramı üzerine bir inceleme. 13. Ulusal Psikolojik Danışma ve Rehberlik Kongresi. 7-9 Ekim, Mersin Üniversitesi \& Türk PDR Derneği, Mersin, Türkiye, 
Denizli, S., Pamukçu, B. ve Meydan, B. (2016). Psikolojik danışma süreç ve sonuç araştırmalarında danışana ilişkin bir değişken: Psikolojik zihinlilik. Mehmet Akif Ersoy Üniversitesi Ĕ̈itim Fakültesi Dergisi, 1(40), 419-431. Doi:10.21764/efd.01537

Denizli, S., Meydan, B. ve Pamukçu, B. (2018). Psikolojik zihinlilik ölçeği Türkçe formu'nun geçerlik ve güvenirlik çalışması. V.International Eurasian Educational Research Congress. 02-05 Mayıs, Akdeniz Üniversitesi, Antalya, Türkiye.

Fayers, P. M. ve Hand, D. J. (1997). Factor analysis, causal indicators and quality of life. Quality of Life Research, 6(2), 139-150. Doi:10.1023/A:1026490117121

Field, A. (2009). Discovering statistics using SPSS (3th ed.). London: SAGE Publications Ltd.

Fraenkel, J. R., Wallen, N. E. ve Hyun, H. H. (2012). How to design and evaluate research in education (8th ed.). New York, NY: McGraw-Hill Companies.

Grant, A. M. (2001). Rethinking psychological mindedness: Metacognition, self-reflection, and insight. Behavior Change, 18(1), 8-17.

Güleç, H., Köse, S., Güleç, M. Y., Çitak, S., Evren, C., Borckardt, J. ve Sayar, K. (2009). Reliability and factorial validity of the Turkish version of the 20-item toronto alexithymia scale (TAS-20). Bulletin of Clinical Psychopharmacology, 19(3), 214-220.

Hair, J. F., Black, W. C., Babin, B. J., Anderson, R. E. ve Tatham, R. L. (2006). Multivariate data analysis (6th ed.). New Jersey: Pearson Prentice Hall.

Hatcher, R., Hatcher, S., Berlin, M., Okla, K. ve Richards, J. (1990). Psychological mindedness and abstract reasoning in late childhood and adolescence: An exploration using new instruments. Journal of Youth and Adolescence, 19(4), 307-326.

Hill, C. E. ve Lambert, M. J. (2004). Methodological issues in studying psychotherapy process and outcome. M. J. Lambert (Yay. haz.), Bergin and Garfield's Handbook of Psychotherapy And Behavior Change (5th ed.) içinde (ss. 84-135). New York: Wiley.

Hu, L. T. ve Bentler, P. M. (1999). Cut off criteria for fit indexes in covariance structural analysis: Conventional criteria versus new alternatives. Structural Equation Modeling, 6(1), 55-65. Doi:10.1080/10705519909540118

İşlegen, G. (2011). Danışanların bağlanma stillerinin ve algıladıkları sosyal desteğin terapötik çalışma uyumunu yordama gücünün belirlenmesi (Yayımlanmamış yüksek lisans tezi). Ankara Üniversitesi, Eğitim Bilimleri Enstitüsü, Ankara.

Johnson, C., Burke, C., Brinkman, S. ve Wade, T. (2017). Development and validation of a multifactor mindfulness scale in youth: The comprehensive inventory of mindfulness experiences-adolescents (CHIME-A). Psychological Assessment 29(3), 264-281. Doi:10.1037/pas0000342.

Kırca, B. (2017). Ergenler için kapsamlı bilinçli farkındalık deneyimleri envanterinin geçerlik ve güvenirlik çalışması (Yayımlanmamış yüksek lisans tezi). İstanbul Sabahattin Zaim Üniversitesi, Sosyal Bilimler Enstitüsü, İstanbul.

Kline, P. (2014). An easy guide to factor analysis. New York: Routledge.

Lambert, M. J. (1992). Psychotherapy outcome research: Implications for integrative and eclectic therapists. J. C. Norcross ve M. R. Goldfried (Yay. haz.), Handbook of Psychotherapy Integration içinde (ss. 94-129). New York, NY: Basic Books.

Lambert, M. J. ve Ogles, B. M. (2004). The efficacy and effectiveness of psychotherapy. M. J. Lambert (Yay. haz.), Bergin and Garfield's Handbook of Psychotherapy And Behavior Change (5th ed.) içinde (ss. 139-193). New York: Wiley.

Landis, J. R. ve Koch, G. G. (1977). The measurement of observer agreement for categorical data. Biometrics, 33(1), 159-174. Doi:10.2307/2529310

Lewis, C. A., Francis, L. J., Shevlin, M. ve Forrest, S. (2002). Confirmatory factor analysis of the French translation of the abbreviated form of the revised Eysenck Personality Questionnaire (EPQR-A). European Journal of Psychological Assessment, 18(2), 179185. Doi:10.1027//1015-5759.18.2.179

Marcoulides, G. ve Schumacker, R. (2001). New developments and techniques in structural equation modeling. London: Lawrence Erlbaum Associates, Publishers. 
McCallum, M. ve Piper, W. E. (1996). Psychological mindedness. Psychiatry, 59(1), 48-64. Doi:10.1080/00332747.1996.11024750

McCallum, M., Piper, W. E., Ogrodniczuk, J. S. ve Joyce, A. S. (2003). Relationships among psychological mindedness, alexithymia and outcome in four forms of short-term psychotherapy. Psychology and Psychotherapy: Theory, Research and Practice, 76(2), 133-144. Doi:10.1348/147608303765951177

McIntire, S. A. ve Miller, L. A. (2005). Foundations of psychological testing (2th ed.). New York: Sage Publishing Co.

Muran, J. C. ve Lutz, W. (2015). A train of thought: 25 years of psychotherapy research. Psychotherapy Research, 25(3), 277-281. Doi:10.1080/10503307.2015.1025483

Nunnally, J. C. ve Bernstein, I. H. (1994). Traditional approaches to scaling. J. C. Nunnally ve I. H. Bernstein (Yay. haz.). Psychometric Theory (3th ed.) içinde (ss. 33-82). New York: McGraw-Hill.

Nyklíček, I. ve Denollet, J. (2009). Development and evaluation of the balanced index of psychological mindedness (BIPM). Psychological Assessment, 21(1), 32-44. Doi:10.1037/a0014418

Nyklíček, I., Majoor, D. ve Schalken, P. A. (2010). Psychological mindedness and symptom reduction after psychotherapy in a heterogeneous psychiatric sample. Comprehensive Psychiatry, 51(5), 492-496. Doi:10.1016/j.comppsych.2010.02.004

Orlinsky, D. E., Rønnestad, M. H. ve Willutzki, U. (2004). Fifty years of psychotherapy processoutcome research: Continuity and change. M. J. Lambert (Yay. haz.), Bergin and Garfield's Handbook of Psychotherapy And Behavior Change (5th ed.) içinde (ss. 3-15). New York: Wiley.

Pallant, J. (2005). SPSS survival manual: A step guide to data analysis using SPSS for windows (2th ed.). Australia: Allen \& Unwin.

Piper, W. E., McCallum, M., Joyce, A. S., Rosie, J. S. ve Ogrodniczuk, J. S. (2001). Patient personality and time-limited group psychotherapy for complicated grief. International Journal of Group Psychotherapy, 51(4), 525-552. Doi:10.1521/ijgp.51.4.525.51307

Robinson, J. P., Shaver, P. R. ve Wrightsman, L. S. (1991). Criteria for scale selection and evaluation. J. P. Robinson, P. R. Shaver ve L. S. Wrightsman (Yay. haz.). Measures of Personality And Social Psychological Attitudes içinde (ss. 1-15). San Diego: California Academic Press.

Roxas, A. S. (2011). The relationships of psychological mindedness and religious coping to psychological distress and adjustment in high-school adolescents (Unpublished doctoral thesis). Fordham University, New York.

Roxas, A. S. ve Glenwick, D. S. (2014). The relationship of psychological mindedness and general coping to psychological adjustment and distress in high-school adolescents. Individual Differences Research, 12(2), 38-49.

Sanberk, İ. (2010). Psikolojik danışman-danışan ilişkisinin çözümlenmesi ve bazı süreç, sonuç değişkenleri açısından incelenmesi (Yayımlanmamış doktora tezi). Çukurova Üniversitesi Sosyal Bilimler Enstitüsü, Adana.

Schumacker, R. E. ve Lomax, R. G. (2016). A Beginner's guide to structural equation modeling (3th ed.). New York: Routledge.

Seçer, İ. (2018). Psikolojik test geliştirme ve uyarlama süreci: SPSS ve LISREL uygulamaları (2.Basım). Ankara: Anı Yayıncılık.

Stiles, W. B., Hill, C. E. ve Elliott, R. (2015). Looking both ways. Psychotherapy Research, 25(3), 282-293. Doi:10.1080/10503307.2014.981681

Sümer, N. (2000). Yapısal eşitlik modelleri: Temel kavramlar ve örnek uygulamalar. Türk Psikoloji Yazllarl, 3(6), 49-74.

Tabachnick, B. G., Fidell, L. S. ve Ullman, J. B. (2007). Using multivariate statistics (5th ed.). New York, NY: Allyn and Bacon.

Trudeau, K. J. ve Reich, R. (1995). Correlates of psychological mindedness. Personality and Individual Differences, 19(5), 699-704. Doi:10.1016/0191-8869(95)00110-R 


\section{Extended Abstract}

\section{Introduction}

The effectiveness of psychological help received by individuals from mental health professionals has been a subject of research for many years. Studies on what factors should be considered to increase the effectiveness of psychological help have been conducted for a long time (Lambert \& Ogles, 2004; Orlinsky, Rønnestad \& Willutzki, 2004). Such studies particularly have focused on variables such as the competence of the counsellor, therapeutic skills, coping strategies, and techniques he/she uses (Beutler et al., 2004; Hill \& Lambert, 2004). However, it should not be forgotten that each client who comes for help has his/her own individual differences. Given that clients come to the process of receiving help in different personality traits, conditions and attitudes, it cannot be ignored that the characteristics of the client have a very important role in the process of receiving psychological help (Clarkin \& Levy, 2004).

When the effectiveness of the process of receiving psychological help is examined, it is suggested that the characteristics of the client have a higher contribution to the explanation of the change in the process compared to other non-therapeutic characteristics involved in the counselling process, and that $40 \%$ of the change after the psychological help process is also dependent on the characteristics of the client (Lambert, 1992). The number of characteristics that can be examined in the client is quite high in the studies conducted on psychological help processes. In the studies to be conducted, it will be quite superficial to evaluate the process and results of receiving psychological help only on the basis of the demographic characteristics of clients. In this context, it seems to be necessary to investigate some personal characteristics of the client. The concept of psychological mindedness, which has emerged as a characteristic of the client in recent years, has been included in the agenda of research on the effectiveness of the process of receiving psychological help (Boylan, 2006; Conte, Ratto \& Karasu, 1996; Denizli, Pamukcu \& Meydan, 2016; Nyklíček \& Denollet, 2009).

The concept of psychological mindedness can be defined in its broadest sense as a kind of interest and ability that allows the individual to understand the underlying causes of the behaviour of his/her own and others (Conte et al., 1996; Grant, 2001). When the literature is examined, it is seen that high psychological mindedness positively predicts the mental health of individuals (Beitel \& Cecero, 2003; Conte, Buckley, Picard \& Karasu, 1995; Trudeau \& Reich, 1995).

When the literature is reviewed, it is seen that there is a limited amount of research on psychological mindedness in adolescents (Boylan, 2006; Hatcher, Hatcher, Berlin, Okla \& Richards, 1990; Roxas, 2011; Roxas \& Glenwick, 2014). In a study conducted by Boylan (2006) on adolescents diagnosed with depression, it was found that the level of psychological mindedness possessed by adolescents did not lead to a significant difference in their rate of benefitting from cognitive behavioural therapy. In this context, considering the fact that the existence and measurement of the concept of psychological mindedness in children and adolescents are controversial and that studies conducted in these age groups are scarce, for the interpretation of the findings obtained in the thesis study by Boylan, it is clear that more findings need to be collected on psychological mindedness found in children and adolescents.

Seen from this perspective, measurement of the psychological mindedness level of both children and adolescents seems to be important for both practitioners and future research. In this regard, the purpose of the current study is to develop a psychological mindedness scale whose validity and reliability studies are conducted on adolescents and to present it to the use of practitioners and researchers.

\section{Method}

As the current study is a scale development study, in each stage of the scale development process, 6 different study groups constructed from 1254 high school students (670 females and 584 males) selected from among the students attending the high schools in the Bodrum district of the city of 
Muğla through the convenience sampling method were used. The ages of the students constituting these study groups range from 14 to 19 ( $x=16.25$, ss=1.85).

In order to create the item pool for the Psychological Mindedness Scale for Adolescents (PMSA), the existing literature on psychological mindedness was reviewed and an item pool consisted of 55 items was formed. After the construction of the item pool, it was submitted to the review of five guidance and psychological counselling experts, one measurement and evaluation expert and one Turkish language expert. In light of the feedbacks received from the experts, some items in the pool were revised and the number of items was increased to 64; thus, the first draft scale was created. This first draft scale was piloted on a sample consisted of 30 individuals and during this pilot application, the participating students were asked to put a mark next to the item they found difficult to understand. On the basis of the feedbacks received from the students, it was decided that there were some difficulties in understanding 8 items. The opinions of a Turkish language expert were sought about these 8 items, and then some corrections were made on them. The reliability and validity studies of the scale were conducted on this final form.

In order to determine the construct validity of PMSA, first Exploratory Factor Analysis (EFA) was conducted. From this EFA, a four-factor construct having 20 items and explaining $50.95 \%$ of the total variance was derived. These four factors and the variance they explain are as follows: Factor-1 (seeking for psychological help) 14.53\%, Factor-2 (psychological interest) $13.65 \%$, Factor-3 (insight) $11.71 \%$ and Factor-4 (capacity for change) 11.05. In order to examine the model fit, Confirmatory Factor Analysis (CFA) was run on another student group. The model fit indices of PMSA were found to be at acceptable levels $\left(X_{2} / \mathrm{sd}=1.51\right.$, RMSEA $=.045$, $\mathrm{RMR}=.075, \mathrm{SRMR}=.057, \mathrm{NFI}=.90, \mathrm{NNFI}=.96, \mathrm{CFI}=.96$, IFI=.96, RFI=.91, AGFI=.89, GFI=.91). As a result of CFA, the four-factor construct of the scale was confirmed. For the criteriondependent validity of PMSA, Toronto Alexithymia Scale (TAS) and the Comprehensive Conscious Awareness Experiences Scale for Adolescents (CCAESA) were used. It was found that PMSA is negatively correlated with TAS and positively correlated with CCAESA at the medium level.

In order to test the reliability of PMSA, Cronbach Alpha internal consistency reliability, split-half reliability and test-retest reliability analysis methods were used. In all the analyses conducted for the reliability of PMSA, the reliability coefficients calculated for the whole scale and its sub-dimensions were found to be good; thus, the whole scale and its sub-dimensions can be argued to have internal consistency and reliability.

\section{Result and Discussion}

In order to provide effective psychological help to adolescents, it is very important to know to what extent they have psychological mindedness. In this connection, it is of great importance to measure adolescents' psychological mindedness to determine and develop characteristics that breed their mindedness. In this way, it will be possible to explore the variables thought to affect the psychological mindedness level of adolescents and to determine the content of preventive studies in this regard. However, no measurement tool developed to measure the psychological mindedness level of adolescents in Turkey and adapted to our culture from international literature has been found. The current study aimed to help fill this void in the literature. In the current study, PMSA was developed and its validity and reliability studies were conducted. In light of the findings obtained in the current study, it was concluded that PMSA is a valid and reliable measurement tool that can be used to determine the psychological mindedness level of high school students.

The four-factor construct obtained after the model fit of PMSA was ensured was named in light of theoretical opinions and related literature as seeking for psychological help ( 5 items), psychological interest (5 items), insight (5 items) and capacity for change (5 items). While each sub-scale shows in itself that the related characteristic is high, a total score can also be obtained from the scale. In PMSA, there are a total of 20 items 5 of which are reverse phrased. PMSA is a five-point Likert-type scale ranging from (1)Not suitable at all, (2)Very little suitable, (3)Partially suitable, (4)Very suitable and (5)Completely suitable. Thus, the minimum score to be taken from 
the scale is 20 while the maximum score is 100 . Higher scores taken from the scale indicate an increasing level of psychological mindedness in the adolescent.

The validity and reliability studies of PMSA were only conducted on 14-19 year old students attending the high schools in the Bodrum district of the city of Muğla. Thus, the validity and reliability studies of the scale in the future research can be conducted in different cities and with elementary or middle school students. In addition, the use of PMSA in studies to investigate the relationship between psychological mindedness and some relevant demographic (gender, grade level, SEL etc.) and continuous variables (empathy, psychological resilience, life satisfaction etc.) is believed to make some contributions to both the validity and reliability findings of the scale and to the process of explaining the concept of psychological mindedness.

\section{Ek-1 (Ergenler için Psikolojik Zihinlilik Ölçeği)}

\begin{tabular}{|c|c|c|c|c|c|}
\hline EPZÖ & 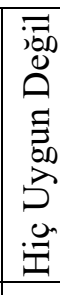 & 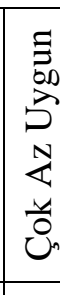 & 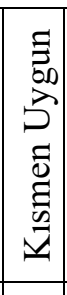 & 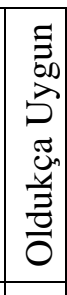 & 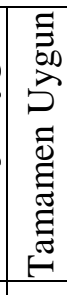 \\
\hline 1. Birisiyle (örn; aile, yakın arkadaş vb.) dertleşmek beni rahatlatır. & $(1)$ & $(2)$ & (3) & (4) & (5) \\
\hline $\begin{array}{l}\text { 2. Başka bir kişiyle konuşmak, sorunlarımı daha iyi anlamama yardımcı } \\
\text { olur. }\end{array}$ & (1) & (2) & (3) & (4) & (5) \\
\hline 3. Çevremdekiler aklıma gelmeyen farklı çözüm yolları gösterebilir. & $(1)$ & $(2)$ & (3) & (4) & (5) \\
\hline 4. Arkadaşlarımla sorunum hakkında konuştuğumda rahatlarım. & $(1)$ & $(2)$ & (3) & (4) & $(5)$ \\
\hline $\begin{array}{l}\text { 5. Çevremdekilerden gelen önerileri deneyip bunların faydasını } \\
\text { görebilirim. }\end{array}$ & (1) & (2) & (3) & (4) & (5) \\
\hline $\begin{array}{l}\text { 6. İnsanların psikolojik sorunlarının temelinde çocukluk yaşantılarının } \\
\text { etkisi olduğuna inanırım. }\end{array}$ & (1) & (2) & (3) & (4) & (5) \\
\hline 7. Davranışlarımın altında yatan nedenleri anlamak benim için önemlidir. & $(1)$ & $(2)$ & (3) & (4) & $(5)$ \\
\hline $\begin{array}{l}\text { 8. Psikolojik sorunların kaynaklarından biri de insanın zihnindeki } \\
\text { düşüncelerdir. }\end{array}$ & (1) & (2) & (3) & (4) & (5) \\
\hline $\begin{array}{l}\text { 9. Bireylerin olaylar karşısında sergiledikleri davranışları, neye göre } \\
\text { seçtiğini merak ederim. }\end{array}$ & (1) & (2) & (3) & (4) & (5) \\
\hline $\begin{array}{l}\text { 10. Çevremdekilerin davranışlarının altında yatan nedenler üzerine } \\
\text { düsünmeyi severim. }\end{array}$ & (1) & (2) & (3) & (4) & (5) \\
\hline $\begin{array}{l}\text { 11. Yaşadığım olaylar karşısında hissettiğim olumlu duygularım bana } \\
\text { kendimle ilgili çok şey öğretir. }\end{array}$ & (1) & (2) & (3) & (4) & (5) \\
\hline $\begin{array}{l}\text { 12. Kendimi (örn; duygularımı, düşüncelerimi, davranışlarımı vb.) } \\
\text { keşfetmeyi severim. }\end{array}$ & (1) & (2) & (3) & (4) & (5) \\
\hline 13. Yaşadığım duyguların farkında olmak bana yarar sağlar. & $(1)$ & $(2)$ & (3) & (4) & (5) \\
\hline $\begin{array}{l}\text { 14. Yaşadığım olumsuz duyguları kabul edersem, kendimi tanımam } \\
\text { konusunda önemli ipuçları yakalayabilirim. }\end{array}$ & (1) & (2) & (3) & (4) & (5) \\
\hline $\begin{array}{l}\text { 15. Olaylar karşısındaki davranışlarım, bana kendimle ilgili çok şey } \\
\text { öğretir. }\end{array}$ & (1) & (2) & (3) & (4) & (5) \\
\hline 16. Çevremdekiler bana nasıl hissettiğimi sorduklarında öfkelenirim. & $(1)$ & $(2)$ & (3) & (4) & (5) \\
\hline 17. Çevremdekiler işime karıştıklarında öfkelenirim. & $(1)$ & $(2)$ & (3) & (4) & $(5)$ \\
\hline 18. Kimseyle konuşamayacağım yaşantılarım var. & $(1)$ & $(2)$ & (3) & (4) & (5) \\
\hline
\end{tabular}




\begin{tabular}{|l|l|l|l|l|l|}
\hline $\begin{array}{l}\text { 19. Çevremdekiler bir şeyin beni rahatsız edip etmediğini sorduklarında } \\
\text { öfkelenirim. }\end{array}$ & (1) & (2) & (3) & (4) & (5) \\
\hline $\begin{array}{l}\text { 20. Psikolog / Psikolojik Danışman da olsa bir başkasının kişisel } \\
\text { sorunlarımı öğrenmek istemesine öfkelenirim. }\end{array}$ & (1) & (2) & (3) & (4) & (5) \\
\hline
\end{tabular}

1.Faktör (Psikolojik Yardım Arama)

Maddeleri: 1-2-3-4-5

2.Faktör (Psikolojik İlgi)

Maddeleri: 6-7-8-9-10

3.Faktör (İçgörü)

Maddeleri: 11-12-13-14-15

4.Faktör (Değişim Kapasitesi)

Maddeleri: 16-17-18-19-20
Düz Maddeler:

1-2-3-4-5-6-7-8-9-10-11-12-13-14-15

Ters Maddeler:

16-17-18-19-20

Ölçekten en az 20, en fazla 100 puan alınmaktadır.

Yüksek puan, yüksek düzeyde psikolojik zihinliliğe işaret etmektedir.

Ölçekten toplam puan alınabilmektedir. 